\title{
FOOD CONSUMPTION AND PELLET REGURGITATION RATES IN A CAPTIVE INDIAN EAGLE OWL (BUво вUво BENGALENSIS)
}

\author{
Mario Eric Ramanujam
}

Gratitude Avian Rehabilitation, Auroville, Pondicherry 605101, India.

\begin{abstract}
An attempt has been made to study the pellet formation/ regurgitation rates of a captive Indian Eagle Owl (Bubo bubo bengalensis). The study conducted over a period of two months indicated the size of the pellet proportional to the quantity of live food intake. However, the varying length of the time taken for regurgitation on different days could not be explained.
\end{abstract}

\section{Introduction}

The food requirements, metabolism, pellet formation/ regurgitation rates of some Strigiformes have been documented (Collins, 1963; Gatehouse \& Markham, 1970; Graber, 1962; Kumar, 1985; Marti, 1973; Mason \& Leffroy, 1912). To the best of our knowledge, the Indian sub-species of the Eagle Owl has never been subjected to such studies. Hence little is known about its dietary requirements, pellet formation, etc.

\section{Methods}

A three year old male Bubo bubo bengalensis weighing approximately $1400 \mathrm{~g}$. was subjected to intensive observation in the summer months of May and June 1999 (when average daynight temperatures recorded were $34.8-26.18^{\circ} \mathrm{C}$ ) in an outdoor aviary measuring $12 \mathrm{ft}$. $8 \mathrm{ft}$. $\mathrm{x} 10 \mathrm{ft}$. high.

Out of three birds in our possession, one bird was chosen as it was tame and approachable at all times, thus allowing the constant monitoring of food consumption and pellet collection which was very important to this study.

Over a two-month period rodents (laboratory rats Rattus norvegicus var., house rat Rattus rattus and mouse Mus sp.) were presented (without tails) for consumption on 16 days. On all other days 75-100 g. of raw lean beef was fed once a day (not all of which was consumed every time). Once a week, on a day following a gorge, the bird was kept without food as a routine precaution to avoid overeating.

Received on 22 February 2000

Accepted on 28 March 2000
Feeding times, lengths and weights of rodents fed, approximate times when pellets were regurgitated, and lengths and weights of pellets were recorded.

\section{Results}

Rodents of known weights and different sizes (ranging from 8 $\mathrm{cm}$. to $21 \mathrm{~cm}$. without tails) were presented to the Owl for consumption. On presentation of the food item the Owl unhesitatingly pounced on it and gripped it tightly with its claws. The food was then transferred to its beak to be swallowed. The smaller and medium sized rodents were swallowed whole, but larger rats were torn into pieces using beak and claws. In the latter case the remains (usually guts/forequarters/head) were weighed and deducted from the original figure - thus giving a fair estimate of the weight imbibed at a time. Average food intake was $61.81 \mathrm{~g}$.

From data collected, pellets were regurgitated between $14 \mathrm{hrs}$. and $28.30 \mathrm{hrs}$. after food was ingested. The pellets were expelled by a retching movement of head and neck and a gaping action of the mandibles. No fixed period between food intake and pellet regurgitation was discernible, neither was the time proportionate to the amount of food eaten; though the pellet size was directly proportionate to the amount of food eaten. For further details refer Table 1.

\section{Discussion}

It is unwarranted to suppose that the data presented in this paper has any relevance to the life of the species in the wild as many inconsistencies prevail in relation to food and feeding behaviour. Programmed to a sheltered existence, waiting for food to be produced at fixed times, the general lack of exercise and the fact that the subject had been handreared tend to make this captive a trifle overweight - it weighed approximately 1400 g., as compared to the known weight of $1100 \mathrm{~g}$. in a wild male (Ali \& Ripley, 1969). This may account for its refusal to swallow large rats, though wild birds must be able to imbibe whole large rodents if they are to survive - our field studies have disclosed even nestling Eagle Owls swallowing entire Mole Rats, Bandicota bengalensis, known to weigh over $200 \mathrm{~g}$. (Prater, 
Table 1. Live food ingestion and pellet regurgitation in a captive Indian Eagle Owl during the course of this study.

\begin{tabular}{|c|c|c|c|c|c|c|c|}
\hline $\begin{array}{l}\text { Species } \\
\text { eaten }\end{array}$ & $\begin{array}{l}\text { Date and } \\
\text { of feedin }\end{array}$ & time & $\begin{array}{l}\text { Weight of } \\
\text { food eaten } \\
\text { (g.) }\end{array}$ & $\begin{array}{l}\text { Date and } \\
\text { of pellet reg }\end{array}$ & $\begin{array}{l}\text { time } \\
\text { urgitation }\end{array}$ & $\begin{array}{l}\text { Weight } \\
\text { of pellet } \\
(g .)^{*}\end{array}$ & $\begin{array}{l}\text { Period between food } \\
\text { eaten and pellet } \\
\text { regurgitation }\end{array}$ \\
\hline R. norvegicus var. & 03.v.1999 & $1830 \mathrm{hrs}$. & 61.76 & 04.v.1999 & $1130 \mathrm{hrs}$. & 5.42 & $17.00 \mathrm{hrs}$. \\
\hline R. norvegicus var. & 05.v.1999 & $1820 \mathrm{hrs}$. & 60.89 & 06.v.1999 & $1645 \mathrm{hrs}$. & 4.26 & $22.20 \mathrm{hrs}$ \\
\hline R. norvegicus var. & 07.v.1999 & $1910 \mathrm{hrs}$. & 59.94 & 08.v.1999 & $1440 \mathrm{hrs}$ & 3.25 & $19.30 \mathrm{hrs}$. \\
\hline R. norvegicus var. & 08.v.1999 & $1840 \mathrm{hrs}$. & 61.17 & 09.v.1999 & $1300 \mathrm{hrs}$. & 4.70 & $18.20 \mathrm{hrs}$. \\
\hline R. norvegicus var. & 12.v.1999 & 1900hrs. & 69.77 & 13.v.1999 & 1300hrs. & 5.10 & $18.00 \mathrm{hrs}$. \\
\hline R. norvegicus var. & 16.v.1999 & $1825 \mathrm{hrs}$. & 71.18 & 17.v.1999 & $2130 \mathrm{hrs}$. & 5.40 & $28.05 \mathrm{hrs}$. \\
\hline Mus sp. & 17.v.1999 & $1900 \mathrm{hrs}$. & 37.11 & 18.v.1999 & $2300 \mathrm{hrs}$. & 3.27 & $28.00 \mathrm{hrs}$. \\
\hline R. norvegicus var. & 21.v.1999 & $1910 \mathrm{hrs}$. & 61.98 & 22.v.1999 & $1900 \mathrm{hrs}$. & 4.85 & $23.50 \mathrm{hrs}$. \\
\hline R. norvegicus var. & 24.v.1999 & $1825 \mathrm{hrs}$. & 61.11 & 25.v.1999 & $1000 \mathrm{hrs}$. & 4.33 & $15.35 \mathrm{hrs}$. \\
\hline R. norvegicus var. & 04.vi.1999 & $1900 \mathrm{hrs}$. & 54.74 & 05.vi.1999 & $2330 \mathrm{hrs}$. & 3.91 & $28.30 \mathrm{hrs}$. \\
\hline R. rattus & 08.vi.1999 & $2030 \mathrm{hrs}$. & 81.18 & 09.vi.1999 & $1330 \mathrm{hrs}$. & 5.89 & $1.007 \mathrm{hrs}$. \\
\hline R. norvegicus var. & 11.vi.1999 & $1830 \mathrm{hrs}$. & 61.12 & 12.vi.1999 & $1415 \mathrm{hrs}$. & 4.82 & $19.45 \mathrm{hrs}$. \\
\hline R. norvegicus var. & 13.vi.1999 & $1900 \mathrm{hrs}$. & 70.14 & 14.vi.1999 & $1500 \mathrm{hrs}$. & 5.11 & $20.00 \mathrm{hrs}$. \\
\hline R. norvegicus var. & 18.vi.1999 & $1830 \mathrm{hrs}$. & 60.15 & 19.vi.1999 & 1700 hrs. & 4.03 & $22.30 \mathrm{hrs}$. \\
\hline R. norvegicus var. & 20.vi.1999 & $1900 \mathrm{hrs}$. & 59.95 & 21.vi.1999 & $0900 \mathrm{hrs}$ & 5.22 & $14.00 \mathrm{hrs}$. \\
\hline R. norvegicus var. & 23.vi.1999 & $1800 \mathrm{hrs}$. & 60.87 & 24.vi.1999 & $0915 \mathrm{hrs}$. & 5.57 & $15.15 \mathrm{hrs}$. \\
\hline
\end{tabular}

${ }^{*}$ Pellets weighed within 15 minutes of being regurgitated.

Table 2. Food consumption and pellet formation/regurgitation rates in six species of captive owls.

\begin{tabular}{|c|c|c|c|c|c|c|}
\hline Taxa & $\begin{array}{l}\text { Mean } \\
\text { weight (g) }\end{array}$ & $\begin{array}{l}\text { Mean food } \\
\text { eaten/day }(g)\end{array}$ & $\begin{array}{l}\% \text { of body } \\
\text { weight eaten }\end{array}$ & $\begin{array}{l}\text { Mean no. } \\
\text { pellets/day }\end{array}$ & $\begin{array}{l}\text { Mean room } \\
\text { temp. }\left({ }^{\circ} \mathrm{C}\right)\end{array}$ & Reference \\
\hline Great Horned Owl (Bubo virginianus) & 1363.3 & 58.3 & 4.3 & 1.2 & 21 & Marti (1973) \\
\hline Barn Owl ( Tyto alba) & 576.7 & 56.7 & 9.8 & 1.6 & 21 & Marti (1973) \\
\hline Long-eared Owl (Asio otus) & 285.2 & 36.9 & 12.9 & 1.2 & 21 & Marti (1973) \\
\hline Burrowing Owl (Speotyto cunicularia) & 156.6 & 26.4 & 16.9 & 1.4 & 21 & Marti (1973) \\
\hline Spotted Owlet (Athene brama) & 123.6 & 21.8 & 17.6 & 1.3 & 31 & Kumar(1985) \\
\hline Indian Eagle owl (B. b. bengalensis) & 1400.0 & 61.81 & 4.41 & 1.17 & 30.49 & Present study. \\
\hline
\end{tabular}

1948). Captives very rarely attempt to eat more than one prey item per day, contrary to wild birds that regularly turn up two or three rodent skulls in a single pellet, occassionally more. This is probably due to the fact that wild birds do not eat every day and must endure periods of food shortage.
Still, many ponderables remain - the case of pellet formation and regurgitation for instance. As mentioned earlier, pellets are expelled between 14 and 28.5 hrs. afrer feeding: cases of owls retaining pellets for up to five days have been recorded (Lloyd \& Lloyd, 1969). No general pattern is discernible and the rationale for owls to retain pellets for extended periods is unclear. All that 
can be said is that it is necesary for captive owls to injest 'live' food as they are important in keeping the birds' digestive tracts healthy. The soft fur or feathers on the outside of the pellet act rather like a swab, cleaning the walls as it passes on the way to be expelled (Lloyd \& Lloyd, 1969). It is a fact that owls fall ill and die when deprived of this roughage - especially the smaller species. This species has been known to survive on meat with only occassional roughage - in the form of dead crows - thrown in at Karachi Zoo (Walker, 1999).

\section{Acknowledgements}

I wish to express my gratitude to Shanta Neville, Dietra Claire Worden and Thomas for their assistance and encouragement.

\section{References}

Ali, S. and S.D. Ripley (1969). Handbook of the Birds of India and Pakistan. Vol. 3. Oxford University Press.
Collins, C.T. (1963). Notes on the feeding behaviour, metabolism and weights of the Saw Whet Owl. Condor 65: 528-530.

Gatehouse, S.N and B.J. Markham (1970). Respiratory metabolism of three species of raptors. The Auk 87: 738-741.

Graber, R.R. (1962). Food and oxygen consumption and pellet formation rates in three species of owls (Strigidae). Condor 64: 473487.

Kumar, T.S. (1985). The life history of the Spotted Owlet (Athene brama brama, Temminck) in Andhra Pradesh. Raptor Research Centre. Lloyd, G. and D. Lloyd (1969). Birds of Prey. Hamlyn Publishing Group Ltd.

Marti, C.D. (1973). Food consumption and pellet formation rates in four owl species. Wilson Bull. 85: 78-81.

Mason, C.W. and H.M. Leffroy (1912). The food of birds of India. Memoirs Department of Agriculture Entomology series 3: 376

Prater, S.H. (1948). The Book of Indian Animals. Oxford University Press, 324 pp.

Walker, S. (1999). A history of the Karachi Zoological Gardens, Pakistan. Zoos' Print 14(12): 22-25.

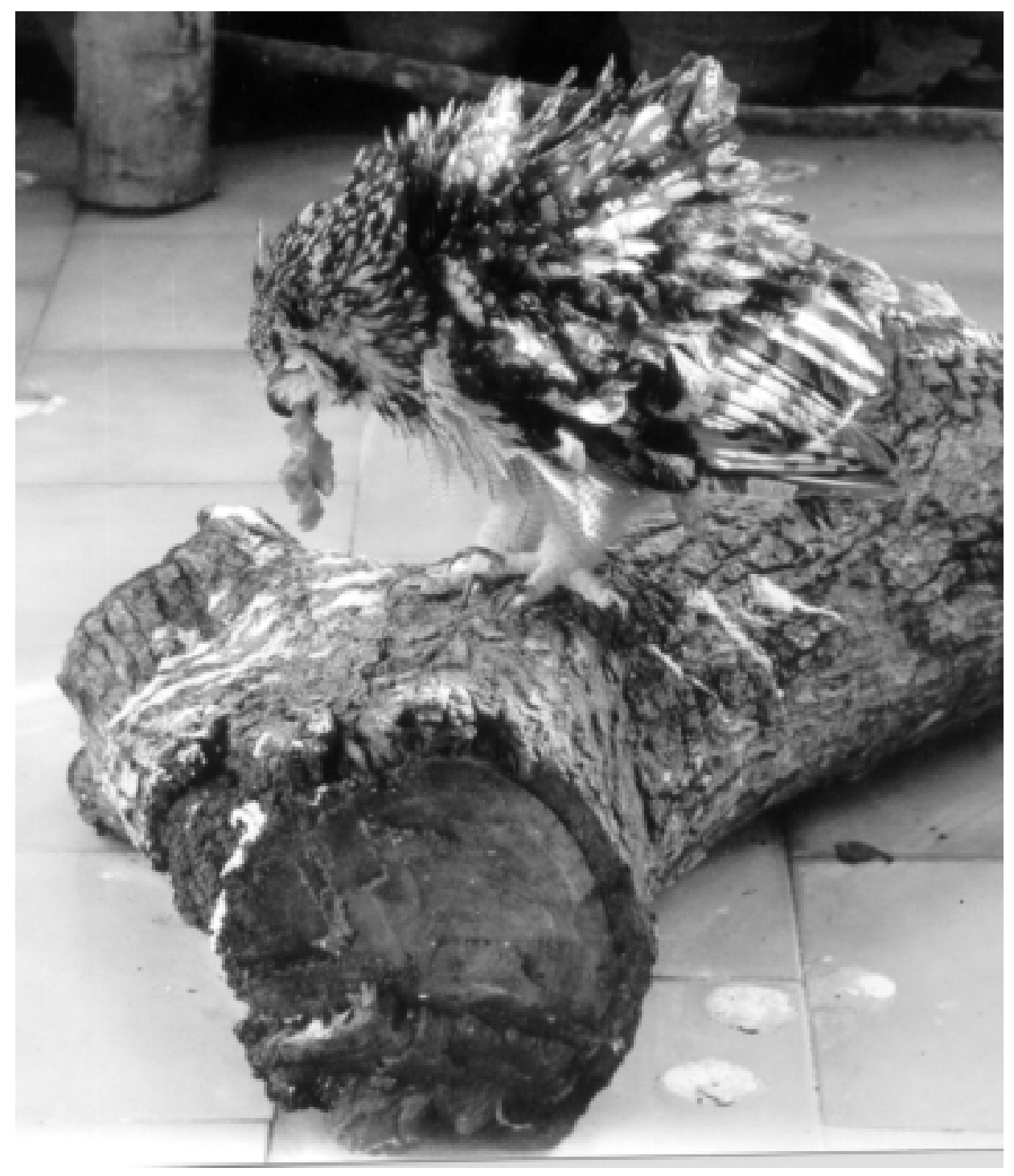

